\title{
HABITUAL CRIMINAL STATUTES: SHIELD OR SWORD*
}

HaBITUAL criminal statutes, designed both to discourage chronic criminality and to safeguard society against incorrigibles, ${ }^{1}$ have been widely enacted during the past 75 or so years. Aside from a few early cases in which their constitutionality was explored and affirmed ${ }^{2}$ these statutes have received little more than perfunctory judicial attention. ${ }^{3}$ However, a novel and noteworthy construction has recently been placed on New Jersey's habitual criminal statute in State v. McCall. ${ }^{5}$ The defendant, who was convicted of breaking and entering, had, on two previous occasions, been convicted of burglary on three and four separate counts respectively. The prosecutor then demanded that the defendant be sentenced to life imprisonment, the penalty exacted by the New Jersey habitual criminal statute of persons who have been

* State v. McCall, 99 A.2d 153 (N.J. Super. 1953).

${ }^{1}$ For a discussion of the purposes and philosophy underlying habitual criminal statutes see 58 A.L.R. 20 (1929).

${ }^{2}$ Graham v. West Virginia, 224 U.S. 616 (1912) (not a denial of life or liberty without due process of law); Moore v. Missouri, 159 U.S. 673 (1895) (not a denial of equal protection of the laws); People v. Mock Don Yeun, 67 Cal. App. 597, 227 Pac. 948 (1924) (not a delegation of legislative authority to the prosecutor); Kelly v. People, 115 IIl. 583,4 N.E. 644 (1886) (does not impose a penalty not proportioned to the nature of the offense); Sturtevant v. Commonwealth, 158 Mass. 598, 33 N.E. 648 (1893) (does not impose an unjust discrimination); People v. Morris, 80 Mich. 634, 45 N.W. 59 I (1890) (does not impose cruel and unusual punishment), People ex rel. Willis, I I App. Div. 4, 42 N.Y. Supp. 25 I (1896) (does not impose double jeopardy). See also Note, 58 A.L.R. 20 (1929).

${ }^{3}$ The more recent cases which have involved habitual criminal statutes have dealt largely with statutory construction, effects of pardons and suspended sentences, insufficient indictments, pleadings and presumptions. These cases are collected in Note, 24 A.L.R.2d 1247 (1952).

'N.J.S.A. 2A:85-12 (1951): "Any person convicted on three separate occasions of high misdemeanors in this state, or of crimes under the laws of the United States or any other state or country, which crimes would be high misdemeanors under the laws of this state, or whose convictions for such offenses in this state or under the laws of the United States or any other state or country shall total 3 or more, and who thereafter is convicted of an offense enumerated in this subtitle, is hereby declared to be an habitual criminal, and the court in which fourth or subsequent conviction is had shall impose a life sentence in the state prison upon the person so convicted.

"Conviction of 2 or more of such crimes or high misdemeanors charged in one indictment or accusation, or in two or more indictments or accusations consolidated for trial shall be deemed to be only I conviction."

${ }_{99}$ A.2d 153 (N.J. Super. 1953). 
convicted of high misdemeanors ${ }^{6}$ on four "separate occasions." Ruling that the statute was properly invoked, the trial court acceded to this demand.

The sentence was affirmed by the intermediate appellate court despite the defendant's contention that the statute was inapplicable since: (I) he had not been convicted on at least four "separate occasions" as was expressly required; and (2) even if he had been so convicted, he had not been incarcerated following these prior convictions as was implicitly required.

That the court erred in holding that conviction on each of several counts in the same trial constituted conviction on a "separate occasion" clearly appears from the statute itself. ${ }^{8}$ However, even if the statute had not expressly defined conviction on a separate occasion, this holding would still be against the weight of authority that two or more convictions on the same day cannot be counted individually within the meaning of the habitual criminal statutes. ${ }^{9}$

In an analogous case arising in the state of Washington, ${ }^{10}$ the defendant was convicted on three informations on the same day. These being construed as individual convictions, he was then sentenced in accordance with the provisions of the state's habitual criminal statute. ${ }^{11}$ On appeal from this sentence the court, unaided as was the New Jersey court by a statutory provision containing the words "separate occasions," nevertheless reversed, holding that convictions on separate occasions were necessarily implied by the statute.

It would appear also that the court erred in failing to recognize that in order to be classified as an habitual criminal one must have been incarcerated following his prior convictions. New Jersey's first habitual criminal statute, enacted in $1898,{ }^{12}$ was directed at second offenders exclusively. Its critical language was: "Any offender who

"In New Jersey criminal practice a "high misdemeanor" is tantamount to felony at common law. E.g., burglary, N.J.S.A. $2 A: 94-\mathrm{I}$ (1953), and rape, N.J.S.A. 2A:138-1 (1953), are denominated as "high misdemeanors" in the New Jersey statutes.

7 See text of statute, supra note 4.

${ }^{8}$ Supra note 4.

${ }^{\circ}$ Biddle v. Thiele, Ir F.zd 235 (1926); Joyner v. State, I 58 Fla. 806, 30 So.zd 304 (1947); People v. Klemick, 3 r I Ill. App. 508, 36 N.E.2d 846 (r94r); People v. Podsiad, 295 Mich. 541, 295 N.W. 257 (1940); State v. McKenzie, r82 Minn. 5 I3, 235 N.W. 274 (1931); Keib v. Mardany, 51 N.Y.S.2d 290 (1944); Ryan v. Nygaard, 70 N.D. 687,297 N.W. 694 (1941) ; Cary v. State, 70 Ohio St. 121, 70 N.E. 955 (r904); Commonwealth ex rel. Turpack v. Ashe, 339 Pa. 403, 15 A.2d 359 (r940); Commonwealth v. Welsh, 2 Va. Cas. 57 (1817); Faull v. State, 178 Wis. 66,189 N.W. 274 (1922).

${ }^{10}$ State v. Jones, 138 Wash. Iro, 244 Pac. 395 (1926).

${ }^{11}$ WASH. REM. COMP. Stat. $\$ 2286$ (r922).

${ }^{13}$ N.J. Laws I 898 , c. $235, \S 2$ I 9. 
shall have been sentenced to imprisonment. . . ." (emphasis added). Thus, in order for an offender to be brought within its purview he must only have previously been sentenced to imprisonment. Reenactments of the statute in $1927^{13}$ and $1937^{14}$ modified the 1898 Act by providing for discretionary life imprisonment of those persons who had been convicted of and sentenced to imprisonment for at least three prior high misdemeanors, and by adding the further prerequisite that each sentence must have been served. The 1940 reenactment ${ }^{16}$ of the statute made life imprisonment mandatory for so-called "four time losers." The $195 \mathrm{I}$ reenactment ${ }^{16}$ added the requirement that prior convictions must have been on "separate occasions" but omitted the express prerequisite that sentences on prior convictions must have been served. It was on the basis of this omission that the court held that the corrective influence of imprisonment was not an integral element of "conviction" under the habitual criminal statute.

This inexplicable omission by the legislature, however, can only have been inadvertent. A basic justification of the heavier penalties imposed on incorrigibles under an habitual criminal statute is their demonstrated imperviousness to the corrective influence of previous imprisonments. ${ }^{1 \tau}$ Accordingly, to invoke such a statute to penalize a recidivist for failure to respond to rehabilitative efforts to which he has never been exposed extends its operation beyond the logical limits of its principle. Yet, this is, in effect, the anomalous result which the New Jersey court has reached.

Through unawareness or purposeful distortion of the unambiguous statutory language, ${ }^{18}$ or through disregard or ignorance of its underlying policy, ${ }^{10}$ the court in this case has perverted and made a mockery of the letter and the spirit of the New Jersey habitual criminal statute.

\section{SANFord HaLberstadter}

${ }^{13}$ N.J. Laws 1927, c. $218, \S \S \mathrm{I}, 2$; c. $263, \S \S 1,2$.

${ }_{14}$ N.J. Laws 1937, $2: 136-4$.

${ }^{15}$ R.S. 2 :103-10, as amended, N.J. Laws 1940, c. 219 , p. 889, § 3 , N.J.S.A.

${ }^{10}$ Supra note 4 .

${ }^{17}$ People v. Rose, 20 Cal. App. 2d 5I3, 79 P.2d 737 (1938).

${ }^{28}$ The construction urged by the defendant had been unequivocally adopted by the New Jersey Supreme Court in State v. Meinkin, 1o N.J. 348, 91 A.2d 721 (1952).

${ }^{20}$ It has been repeatedly held that the opportunity for rehabilitation is an integral part of the philosophy behind the habitual criminal statutes. Morgan v. Commonwealth, 170 Ky. 400, I86 S.W. 132 (1916); Rand v. Commonwealth, 9 Gratt 738 (Va. 1852); State ex rel. Stover v. Riffe, 128 W. Va. 70, 35 S.E.2d 689 (1945). Contra: State v. Dale, I10 Iowa 215,8 I N.W. 453 (1900). 